\title{
Exploring Shifts in Conceptions of "Good" Citizenship: Community Service-Learning in Activist Placements
}

\author{
Donna Chovanec, Tania Kajner, Ayesha Mian, Misty Underwood \\ University of Alberta
}

chovanec@ualberta.ca, tkajner@ualberta.ca, amian@ualberta.ca, underwoo@ualberta.ca

\begin{abstract}
In this paper, we share insights about citizenship from a research project that investigated the effects of a service-learning experience in a graduate adult education seminar with an explicitly critical pedagogical focus and activist placements. We analyze a subset of the findings related to students' shifting conceptions of themselves as citizens and the factors that facilitated these shifts.
\end{abstract}

\section{Introduction}

In recent years, service learning has become prominent in both K-12 education and higher education. Generally, service-learning is used to provide students with "real world" experiences, promote citizenship, and encourage students' moral development and sense of social responsibility. However, critics suggest that service-learning often fixates on certain kinds of citizenship experiences, namely, those that maintain a charitable or voluntary orientation that fail to tackle the root causes of the injustices or the social issues that the placements seek to address (Kahne \& Westheimer, 2006; Westheimer \& Kahne, 2004). Nor, some say, does service-learning typically delve into critical issues such as the presumption of neutrality, privileging of Whiteness, and imbalance of power relations that support social inequalities (Butin, 2003).

In a community service-learning (CSL) research project conducted with a graduate course in a western Canadian university, the research team used Westheimer and Kahne's (2004) citizenship framework as a heuristic device to prompt discussion and reflection in course assignments and research interviews. While recognizing the existence of a plethora of citizenship models and frameworks, and contestations in understandings of citizenship, we chose this framework for multiple reasons: it is an accessible framework for students; it makes explicit links between citizenship and CSL activities; and its critique of mainstream service-learning models is congruent with the critical pedagogical approach and activist placements used in the course.

Our analysis of course assignments and post-course interviews revealed that many students experienced noticeable shifts across the three citizenship categories outlined in the model, particularly in their identification with activist citizenship, akin to Westheimer and Kahne's "justice-oriented citizen." Moreover, these shifts occurred in the identities of both inexperienced and experienced activists.

In this paper, we explore these shifts in students' conceptions of themselves as citizens. First, we briefly summarize conceptualizations of citizenship, especially focusing on the 
framework employed in this study. We follow this with a review of our research process and methods. We then describe a subset of themes from the research findings, i.e., those related to shifting conceptions of citizenship - in identity, in expression and in awareness - and the motivators and facilitators of those shifts, i.e., learning from others, strong theory-practice link and disruptive learning. We finish with a discussion and critique of our findings in relation to the literature on service-learning and implications for CSL placements.

\section{Conceptualizing Citizenship}

In Educating the "Good" Citizen: Political Choices and Pedagogical Goals, Westheimer and Kahne (2004) explore competing visions of citizenship embodied in ten school-based service-learning projects aimed at teaching democratic citizenship. Pointing to contested understandings of "what good citizenship is" and "what a good citizen does," the authors present a citizenship framework that includes the personally responsible citizen, the participatory citizen and the justice-oriented citizen.

- The personally responsible citizen is characterized as one with good character who is honest and law abiding and who contributes time or money to charitable causes. Programs, such as character education, emphasize this individualistic notion of citizenship.

- The participatory citizen believes that solving social problems requires citizens who actively participate and take leadership in established structures. Programs might focus on how government works and strategies for responding to community concerns.

- The justice-oriented citizen is one who calls attention to matters of injustice, addresses the root causes of social issues, critically assesses social, political and economic structures and considers collective strategies for systemic change. Programs might teach about social movements, structural inequalities and social change strategies.

While the personally responsible citizen might donate to the food bank, the participatory citizen might organize the food drive and the justice-oriented citizen might ask questions about why there is a need for a food bank.

By mapping typical CSL activities onto their framework, Westheimer and Kahne observed:

A vast majority of school-based service learning and community service programs embrace a vision of citizenship devoid of politics; they often promote service but not democracy. They share an orientation toward volunteerism and charity and away from teaching about social movements, social transformation, and systemic change... We find the emphasis placed on personal responsibility and character an inadequate response to the challenges of educating a democratic citizenry. (p. 3)

Although their framework is one of the most widely cited frameworks in the literature that links CSL and citizenship, other models have also been developed to theorize or explain the different approaches to civic involvement. Citing various authors, Wang and Jackson (2005) argue that discussions of citizenship focus mainly on how the concepts of 
charity and social justice are related to each other, either as "two ends of a continuum with social justice as the preferred outcome" or "as distinct paradigms [where one is not] superior to the other" (p. 39), perhaps suggesting either a normative or a neutral approach to the question.

A provocative example of a more normative approach is from Tupper (2007) who considers the distinctions between "care-less citizenship" wherein one "denies or ignores the false universalism embedded in liberal democracies, and so fails to be aware of and thus understand the deep inequities that exist in the world" (p. 259) and "care-full citizenship" characterized by "a deep sense that individual and group actions may have profound sociopolitical effects and that we must take care to understand as best we can how differences shape the degree to which we are able to engage as citizens in the world" (p. 260).

Other categorizations of citizenship include Veugelers' (2007) conceptualization of the adapting, individualistic and critical-democratic citizen and Cogan's (1998) model of "multidimensional citizenship" with four dimensions "of thought, belief and action" (drawing from Marshall's classic work of 1950). Gandin and Apple (2002) distinguish between thin and thick democracy to differentiate approaches to citizenship education, while Taylor (1998), also drawing on Marshall, proposes four ideal models of citizenship representing different approaches to linking social actors to the state, and argues that competing models of citizenship generate distinct experiences of democratic politics in the everyday lives of individual citizens. On the other hand, Moyer (2001) suggests that the four roles of social activism - citizen, rebel, change agent and reformer - are all required to "successfully create social change" (p. 21).

In this research project, while recognizing that no model can claim fixed or rigid categories of citizenship, ${ }^{1}$ we opted to use the Westheimer and Kahne (2004) framework as a prompt to unearth how students situated themselves over time in relation to their conceptions of themselves as citizens and as activists, particularly because the authors explicitly address the role of service-learning within their citizenship model.

\section{Research Process and Methods}

The insights presented in this paper are drawn from a research project in which we investigated the effects of a community service-learning experience in a graduate adult education seminar with an explicitly critical pedagogical focus. In this study, we invoked critical pedagogy as a means of problematizing predominant CSL models that do not sufficiently explore or challenge unequal relations of power and social structures. We asked: How might a critical/radical CSL pedagogy inform a critique of service-learning in post-secondary contexts?

\footnotetext{
1 Students themselves provided a critique of the framework, much of which we share. First, the link between citizenship and the state as an authority is rejected by many anarchists, and was therefore problematic for those students. Others saw the framework as too static, with overly simplified and discreet categories. Some found the framework inadequate in capturing the complexities of the interaction between intent and action and in capturing changing conceptualizations of the same activity over time. Finally, the framework implies a developmentally linear approach whereby students progress over time toward the more "desirable" end of the spectrum.
} 


\section{The Course}

The instructor of a graduate course on "learning in social movements" initiated this research project in order to examine the impacts of service-learning on her students. The course focuses on the pedagogical dimension of social movements, including experiential, transformative, social and political learning. The in-class component was supplemented by CSL placements in activist organizations. Students generally attended meetings of the activist organizations during the term and activists worked with the students on campus after every class, including a mid-term half-day working session. A small minority of students were also members of the activist organizations.

\section{Methods}

The course instructor obtained university ethics approval and student consent to collect and review students' homework assignments and to conduct semi-structured interviews six months to two years after they completed the course. We used the university's learning management system to obtain consents, upload homework assignments and conduct a short anonymous online survey. Fifteen students who had completed the course over the previous two years participated in the project.

Because the principal investigator was also the course instructor, we paid special attention to ethical issues related to privacy and participant rights, but we have faced ongoing issues related to power. In order to increase the students' opportunity to speak openly, no interviews were conducted by the principal investigator. Nonetheless, we attended carefully to possible social desirability bias, including flattering responses about the course instructor, course design, and overall educational experience.

The theoretical framework that guided our analysis follows from the course in that both are informed by critical pedagogy (Allman, 2001; Horton \& Freire, 1990). With roots in Marxism and critical theory, critical pedagogy is concerned with the inevitably political nature of educational practices; educators aim to develop a capacity for critical judgment and a commitment to the social world among students (Giroux, 2006). Through this theoretical lens, we engaged in a thematic analysis of the interview transcripts and homework assignments. Our use of the Westheimer and Kahne (2004) citizenship framework in the study prompted an avenue of analysis that focuses on the students' conceptualizations of themselves as citizens. We focus on this analytical subset in this paper.

\section{Findings}

In our preliminary analysis, we found that students' perceptions of "good" citizenship, and their understandings of themselves as citizens, shifted throughout the course and after course completion. This prompted us to interrogate the data further to determine what motivated or facilitated these changes.

\section{Shifting Conceptions of Citizenship}

We noticed a pronounced shift in students' conceptions and understandings of their citizenship specifically in relation to activism. We noticed these changes amongst students who were new to activism as well as those students who entered the course with extensive activist experience. We found these changes manifested primarily in the fifteen 
students' shifting understanding of three elements related to citizenship and activism: identity, expression, and awareness.

\section{In Identity...}

Whether or not students identified as activists before the course, many grappled with their identities as activists and as citizens, and often reported profound shifts in both.

The coursework, discussions, and participation in the CSL placements encouraged students to challenge stereotypical conceptions of what an activist looks like and what an activist does. As students made connections between activism and their own concerns and actions, they began to recognize activism in their daily lives. Two students became outspoken advocates for personal causes. Some students who did not initially perceive that they had any prior activist experience began to re-conceptualize themselves as activists. This is reflected in one student's homework assignment:

Does activism mean to lead to radical change? Can I do that by leading or living without the title of activist? I ask this because I think of my own life, as a lesbian... By living openly in my life, conscientiously, am I not radical simply because I do not engage in a mentality of fighting or resisting?

Instead, the student "realized that whether or not I actually acknowledged it, I'm an activist in my everyday life." The choice to live openly and visibly as a sexual minority, an identity that is not always recognized in the state's laws and policies, challenges ideas of legitimate citizenship that might be held by citizens who responsibly follow the rules of the state. The student recognized that her identity itself is an open challenge to the status quo and a claim for social justice.

Three students, already activists upon entering the course, experienced a continuous struggle to understand their personal activist identities and who they were as activists. One of these students, who entered the course with years of experience in a variety of activist environments, commented: "I did re-evaluate 'what does it mean to be an activist?'" Yet, there were also an equal number of students who acknowledged that they learned a lot about activism through the course but still would not consider themselves activists. Through such reflections, students became aware that activist identities could present in multiple and changing ways.

\section{In Expression...}

Some students not only began to perceive themselves as activists but also realized that the myriad of daily actions and decisions they take by living their lives in a social justiceoriented way were as important as more visible activist actions such as attending protests. In considering their past and present actions, students realized that, just as a single activist identity does not exist, nor is there a single way to act upon those activist identities. The expression of activism can take many forms, changing over time and across contexts.

In some cases, students expanded their repertoire of engagement with their issues and actions. For example, even if students engaged in the same actions before and after the 
course, they were more apt to analyze root causes and "go deeper into the issues." One student remarked:

I came out a little bit more willing to look at the depth of what we do in the classrooms.... Every year our kids donate something to the food bank but for the most part they're not really thinking about why... They pat themselves on the back for doing a good job and they think, "well, I've done something to fix hunger. Right?" Whereas I think I'm a little more committed now to looking with them at the root causes of it.

Problematizing classroom practices and introducing a more critical analysis of the social issues being addressed through the activities reflects a shift in how this student expresses his responsibility as an educator.

While service-learning is often seen as a mechanism to encourage student participation in civic life, students who were already highly involved also gained from the experience in various ways. For example, the placements expanded their understanding of activism, while also challenging pre-conceived notions of leadership. One reflected:

I'd considered myself an activist before and I continue to consider myself an activist but I guess maybe what that means has changed a bit... I think before I looked more at an activist... maybe almost in more of a like a vanguard approach, where... several enlightened individuals kind of riled the masses and then led them or something. But now I see the role of an activist as much more organic.

Thus, students became aware that citizens work through numerous channels and in different ways based upon their different positionalities to achieve social change. What it means to be an activist and to take action expanded to include a breadth of social justiceoriented activities.

\section{In Awareness...}

Finally, we noticed a shift in every student's overall awareness of social issues and their acknowledgement that, once we are aware of the reality of the world around us, it is very difficult to ignore it. One student who was new to activism noted: "The class has broadened my critical lens for looking at issues... As a result of this class and my experiences, I will not be able to turn a blind eye to issues as easily as before."

Students also began to see that we examine the world from particular positionalities that greatly affect our engagement and involvement in issues. Many became more conscious of their privilege in the world and their complicity in systems of oppression. One student reflected:

I think that I have been a sub-conscious protector of the status quo for the simple reason that the status quo has been reasonably good to me and to those near me. I hope that I am able to teach citizenship in a new way by actually examining a particular issue and causes of the injustices before simply being charitable to the issue.

The students' exposure to social issues in the work of the activist organizations and the opportunity for social analysis in the classroom allowed them to open their eyes to the world around them and to develop a heightened consciousness of their responsibilities. 


\section{Facilitating Shifts in Citizenship}

After analyzing shifts in identity, expression and awareness related to the students' understandings of citizenship and activism, we wondered what motivated and facilitated these changes. As one student observed: "Well, I mean, you can kind of guess when people had a completely ignorant attitude towards Aboriginal people in general and then they became fierce advocates for indigenous rights and, you know, where's the intervening variable?"

Despite his conviction that the course/CSL combination facilitated such changes, in reality, it is impossible to confidently attribute student changes to any one source. Overall graduate school experiences or changing life experiences throughout this time might also be contributing factors to the students' changes in their ideas of citizenship. It is also difficult to know the extent to which these shifts will be maintained or furthered over time.

With these caveats in mind, our analysis suggests that the critical pedagogical approach in combination with the activist placements may have contributed to the students' shifting conceptions of citizenship by means of three main elements: (1) learning from others, (2) strong theory-practice link, and (3) disruptive learning.

\section{Learning From Others}

Many students commented on the positive impact of learning through interactions with others in the course and placements. Sharing personal experiences with activism and observing other students think and act through the process provided opportunities for extremely powerful learning. One student reflected that he "identified very strongly with the 'personally responsible' citizen, who was a quality, law abiding citizen and contributed to a couple of causes... However, after some exposure to the diverse interests and causes of classmates, I think that in a number of regards I either am, or can become, a 'participatory' citizen."

In contrast, through discussions and class activities, experienced activists sometimes recognized that "activism is a lifelong process" such as in the following example:

Listening to [a guest speaker] speak about activism over a lifetime made me realize that I'm in the process of moving beyond the socially-expected 'radical undergrad' phase... Listening to my classmates and thinking about things [the instructor] said, I've made my decision to commit to social justice principles throughout my life, not just chalking it up to a young-adult phase.

These examples suggest that an outcome of group participation and engagement with others who were also experimenting with or exemplifying social justice citizenship was a shift in their understanding of oneself as a citizen.

\section{Strong Theory-Practice Link}

The CSL experience provided an opportunity for students to link theory and practice. As students were simultaneously exposed to theories in the classroom - such as those related to marginalization, power and privilege and social movement learning - alongside social justice practice in the activist organizations, they began to make important connections 
between the two. The placement gave students the opportunity to participate in activism, not just read about it. As one student stated: "One thing I took away from the class was kind of a concept [of] praxis: the idea that you kinda have to both consider social movement theory as well as act on whatever theory it is... [to] put the learning into something tangible." Another student recounted the experience of watching consensusbased decision-making in action:

They're attempting to live their thinking... [in] trying to decide [what] they should do with the bathrooms at the Bookfair and because you know they're bound to this idea of consensus... But what I could see happening is that, in working through to a decision, they were working through the issues and clarifying it for themselves dialogically... I could see it happening, right? I could see... praxis.

The experience of praxis was instrumental in developing a growing critical consciousness about the world and their place in it as well as tools for critical social analysis.

\section{Disruptive Learning}

The placements provided a disruptive learning experience that unearthed and challenged tacit assumptions and fears of the "other," enabling new perspectives to arise. One student observed the experience of a fellow student:

She was in fact terrified by the fact that she might be working with anarchists, you know, they're gonna be wearing black masks and have guns and stuff, right? But she was very brave and she trusted [the instructor] and she was like, "okay, I'm gonna do it." And she did it. And they didn't attack her, which was nice. And she got to like them and she really learned from them and they absolutely, ABSOLUTELY, changed the way she looks at anarchy. Absolutely.

Another student recalled the first day of class when the instructor presented the students with limited options for their placements:

[We were] left with Anarchist Bookfair and this Anarchist Black Cross, neither of which I really know a lot about and couldn't seem to really get a lot of information from them. And it was like, "you gotta pick today" kind of thing. And I found that really pushed boundaries for me a lot, and I [was] fairly uncomfortable with that so it didn't really feel like a whole lot of choice. That wasn't what I was expecting... I would've expected more variety and yet it seemed like two [placements] were sort of different angles of the same thing.

Although students initially experienced anxiety and discomfort with the lack of choice and the radical placement options provided, most later reported that the placement experiences were ultimately positive and acknowledged that the initial disruption had enhanced their learning experience (Chovanec, Kajner, Mian \& Underwood, 2011). As the student quoted above observed: "It worked out fine."

In essence, the disruption compelled students to participate in actions they might otherwise have shied away from and allowed for active learning and critical thinking, which ultimately challenged and expanded their pre-existing notions of citizenship and activism. 
Thus, while using the Westheimer and Kahne (2004) framework as a tool for considering the students' notions of themselves as citizens, we uncovered shifts in their identities as citizens and activists, in expressions of their citizenship, and in their awareness of social issues and their own complicity in systemic injustice. We observed that these shifts were, in part, facilitated through the experience of learning from others, a strong link between the theory in the classroom and the practice in the placements, and a learning experience that was generally disruptive and challenging.

\section{Discussion}

In analyzing our findings further, we sought guidance from the literature wherein we found three factors that are thought to strengthen the outcomes of community servicelearning towards a social justice orientation, i.e., collegiality, reflection and the intensity of the service-learning experience. An analysis of these factors in relation to the findings explicated above provided both reinforcement and critique of our preliminary understandings of the CLS experiences and outcomes observed in this study.

\section{Collegiality}

Collegial relationships with professionals in the field have been identified as a salient factor in achieving CSL objectives (Furco, 2003). An analysis known as the "comparing models study" found that high levels of collegiality and attention from those at the service-learning placement resulted in a greater development of skills and actions that are necessary to confront social problems (Eyler \& Giles, 1997). One such study suggested that skill development acts as a bridge to greater levels of complex understanding of power and privilege (Prentice, 2007).

Many students in our study reported that they learned from the experiences of others, especially the more experienced activists, in the classroom and in the placements. Moreover, despite their initial apprehension about working with "activists" especially "anarchists," they generally felt comfortable in the placements. The welcoming atmosphere from the placements provided a safe environment in which students could question and explore previously held notions.

That being said, some students felt disconnected from their placements for one reason or another. One stated, "I did not feel like a participant... [but] a very strong observer" and another said, "[the issue] wasn't a passion for me." Many critics of CSL discuss the short timeframe of placements within which single, short term projects are expected to fit into an academic term (Martin, SeBlonka \& Thyron, 2009). While collegiality may indeed emerge in this context in order to facilitate the efficient completion of a graded project, developing an in-depth understanding of how different people in different social positions understand the world is complex, time-consuming, and requires deep reflection. That some students were initially fearful of activist groups speaks to the kind of "othering" that is a starting point for many students approaching new communities.

With the exception of a few students who were already involved with the activist groups prior to the course and a handful that remained involved after the course, students in this study did not have prolonged contact and immersion with their placement organizations. Yet, as Clark and Nugent (2011) explain, the literature on power in service-learning highlights the importance of long term emersion, and strong relationships, and to 
establishing an identity in relation to the "other." An activist identity and understanding of oneself as a social justice-oriented citizen can emerge out of an encounter with an "other" if structured in a way that supports critical examination of power in the CSL experience. Otherwise, the CSL experience could merely result in increased social capital for a group of people who, by virtue of their participation in higher education, are already privileged.

\section{Reflection}

Multiple studies demonstrate that reflection is a key component in reaching critical learning objectives. Reflective activities include writing, class discussion, journaling and presentations (Eyler \& Giles, 1997; Eyler, Giles, Stenson \& Gray, 2001; Omoto, 2005). CSL authors particularly point out that reflective assignments that challenge assumptions and beliefs are essential in aiding students to explore their own experiences and to connect classroom theory with the practice in their placements (Eyler \& Giles, 1999). According to Omoto (2005), reflection is also cited as an important factor in increasing students' awareness of their own civic growth. Further, reflection is a critical component of praxis which, in this case, is demonstrated through the connection between theories in the classroom and practices in the activist organizations.

In the graduate course studied here, students completed regular reflective homework assignments with a focus on questioning taken-for-granted assumptions and worldviews. They were asked to reflect on power, inequality, injustice and their own social positioning. Our analysis of these assignments revealed that students used these opportunities to question social structures and their own positionality and to connect classroom theories to their placement experiences. A number of students recommended that even more of this kind of reflective process be incorporated in the course.

However, the ways in which students' reflections might translate into citizenship practices is complex and impossible to ascertain within the parameters of this study. In view of one student's comment about constructing her reflective assignments around what she thought the instructor would reward, caution is needed in assessing the extent to which students' reflections can be taken as evidence of transformation. Further, reflective approaches must be carefully evaluated for authentic criticality or the CSL experience could devolve into nothing more than a pedagogical tool to promote student growth.

\section{Intensity}

Finally, the literature identifies that the intensity of the service-learning experience significantly affects the learning and experiential outcomes of the students (Eyler, 1993; Kraft \& Krug, 1994). Intensity includes being confronted by new ideas, having opinions challenged and experiencing opportunities to apply content from the classroom to the service-learning placement (Eyler \& Giles, 1997). Also, students who participate in two or three service-learning programs are more likely to stretch themselves into the social justice orientation identified by Westheimer and Kahne (Prentice, 2007).

In the course studied here, the intensity of service-learning was accomplished largely through the intense disruptiveness the students experienced related to the placements themselves. In response to being directed only to selected activist groups for their community service-learning placements, students experienced considerable anxiety about 
the placements, questions about self-efficacy, and discomfort with the radical nature of the placement options particularly in relation to future employment and their own (mis)conceptions about the activist organizations. The process of engaging the students in these activist placements was part of a purposeful and consciously directed "pedagogy of disruption."

But why would an instructor want students to feel disrupted? Critical pedagogues often challenge the "feel good" notion of pedagogy. As one instructor reported in a study conducted with critical pedagogues at the University of Alberta in the 90s, "at least certain kinds of learning may happen more readily if you don't feel good" (Scott \& Chovanec, 1994, p. 35). Critical pedagogues such as Freire (2004) demand that students feel "indignant" and critical race theorists critique the premises behind a "safe dialogue" about race, asking "safe for whom?" and insisting that the conflict and tension be surfaced $(\mathrm{Ng}, 1995)$. Feeling bothered and disrupted are a conscious part of a learning process wherein the intent is to challenge assumptions and ask critically engaged questions.

Further, the disruptive pedagogy employed here enabled an experience of what it means to be denied power, which some authors argue is a crucial component of service-learning experiences that seek to avoid creating a power imbalance between the "server" and the "served" in CSL placements (Clark \& Nugent, 2011).

Through critical pedagogy and disruptions of this nature, the activist placements facilitated deep reflections, new understandings about activists as colleagues, and a level of intensity that could prompt movement into a justice-oriented level of citizenship.

But, is it enough? Did this service-learning experience, situated as it was within the power-infused time and grading constraints of the academy, encourage the development of activist-oriented citizenship? Did it break through systems of social reproduction? Did it serve to interrupt the perpetuation of injustices based on dominant groups' monopoly on power? These are difficult but important questions to ask about the impact of the CSL experience and its relationship to activist citizenship.

\section{Summary and Implications}

In this paper, we reported on the findings from a research project that examined the citizenship implications of community service-learning placements in activist placements. Using the citizenship framework posited by Westheimer and Kahne (2004) as a tool for reflection, our analysis revealed that students shifted their conceptions of "good" citizenship and of themselves as citizens. We also discovered that learning from others, theory-practice linkages between classroom and placement, and disruptive learning experiences contributed to these shifts. We learned that the literature on servicelearning provides both support and critique of our findings by pointing to reflection, collegiality and intensity as critical elements in advancing justice-oriented servicelearning.

While community service-learning is often practiced in ways that facilitate students' service to community, critics claim that many service-learning experiences tend to promote charity or character-building through personally responsible citizenship, or sometimes civic leadership through participatory citizenship (Westheimer \& Kahne, 
2004). In this project, we have demonstrated that CSL placements can be used effectively within a critical pedagogical approach to provide deeper and more challenging learning experiences that can facilitate justice-oriented citizenship.

Based on our findings, we suggest that instructors consider the pedagogical possibilities and advantages of moving away from "safe" placement options that promote personally responsible or participatory forms of citizenship and consider moving towards edgier, more radical placement options that encourage students to engage in justice-oriented forms of citizenship that demand attention to root causes of inequality and injustice. While such placements can be intense and disruptive, we contend that, with the careful and conscientious practice of critical pedagogy in the classroom, activist placements can greatly enhance the learning experience.

We also discovered that CSL in activist placements is a valuable practice for students who are already experienced activists, especially when they are encouraged to have new experiences with new organizations, and when they are challenged to explain their work to others who may not share their values and causes. This may serve to disrupt the tacit assumptions they have developed through interaction in particular forms of activism within familiar organizations, leading to deeper learning and more effective social action.

Thus, to return to our overarching research question, "How does a critical/radical CSL pedagogy inform a critique of service-learning in post-secondary contexts?," we contend that an important implication of our findings is to legitimize the combination of critical pedagogy and critically engaged service-learning as a valid and effective pedagogical approach that promotes justice-oriented citizenship in formal educational settings.

Equally important, however, is the need to engage in continual reflection and critical questioning of CSL: its intent, models and impact. To promote social justice through activities and models that do not themselves embody a justice approach that interrogates power and privilege is highly problematic.

\section{References}

Allman, P. (2001). Critical education against global capitalism. Westport, CT: Bergin \& Garvey.

Butin, D. W. (2003). Of what use is it? Multiple conceptualizations of service-learning in education, Teachers College Record, 105(9), 1674-1692.

Chovanec, D., Kajner, T., Mian, A., \& Underwood, M. (2011). Disrupting the hegemony of choice: Community service learning and activist placements. Proceedings of the Canadian Association for the Study of Adult Education. Toronto: OISE/ University of Toronto.

Clark, A., \& Nugent, M. (2011). Power and service-learning: Salience, place and practice. In B. Porfilio \& H. Hickman (Eds.), Critical service-learning as revolutionary pedagogy: A project of student agency in action (pp. 3-28). Charlotte, $\mathrm{NC}$ : Information Age Publishing. 
Cogan, J. (1998). Citizenship education for the $21^{\text {st }}$ Century: setting the context. In J. Cogan \& R. Derricott (Eds.), Citizenship for the $21^{\text {st }}$ Century: An international perspective on education (pp. 1-20). Sterling, VA: Stylus Publisher.

Eyler, J. S. (1993). Comparing the impact of two internship experiences on student learning. Journal of Cooperative Education, 29(3), 41-52.

Eyler, J. S., \& Giles, D. E., Jr. (1997). The importance of program quality in servicelearning. In A. S. Waterman (Ed.), Service-learning: Application from the research (pp. 57-76). Mahwah, NJ: Erlbaum.

Eyler, J. S., \& Giles, D. E., Jr. (1999). Where’s the learning in service-learning? San Francisco: Jossey-Bass.

Eyler, J. S., Giles, D. E., Jr., Stenson, C. M., \& Gray, C. J. (2001). At a glance: What we know about the effects of service-learning on college students, faculty, institutions and communities, 1993-2000. (3rd ed.). Retrieved March 17, 2010, from http://www.compact.org/resource/aag.pdf.

Freire, P. (2004). Pedagogy of indignation. Boulder: Paradigm Publishers.

Furco, A. (2003). Issues of definition and program diversity in the study of servicelearning. In S. H. Billig \& A. S. Waterman (Eds.), Studying service-learning: Innovations in education research methodology (pp. 13-33). Mahwah, NJ: Erlbaum.

Gandin, L. A., \& Apple, M. W. (2002). Thin versus thick democracy in education: Porto Alegre and the creation of alternatives to neo-liberalism. International Studies in Sociology of Education, 12(2), 99 - 116.

Giroux, H. A. (2006). Academic freedom under fire: The case for critical pedagogy. College Literature, 33(4), 1-42.

Horton, M., \& Freire, P. (1990). We make the road by walking: Conversations on education and social change. Philadelphia, MA: Temple.

Kahne, J., \& Westheimer, J. (2006). The limits of efficacy: Educating citizens for a democratic society. PS: Political Science and Politics, 39(2), 289-296.

Kraft, R. J., \& Krug, J. (1994). Review of research and evaluation on service-learning in public and higher education. In R. J. Kraft \& M. Swadener (Eds.), Building community: Service-learning in the academic disciplines (pp. 197-212). Denver, Colorado: Campus Compact.

Martin, A., SeBlonka, K., \& Tryon, E. (2009). The challenge of short-term service learning. In R. Stoeker \& E. Tryon (Eds.), The unheard voices: Community organizations and service learning (pp. 57-72). Philadelphia, PA: Temple University Press.

Moyer, B. (2001). Doing democracy: The MAP model for organizing social movements. Gabriola Island, BC: New Society Publishers.

$\mathrm{Ng}$, R. (1995). Teaching against the grain: Contradictions and possibilities. In R. Ng, P. Staton \& J. Scane (Eds.), Anti-racism, feminism, and critical approaches to education (pp. 129-152). Toronto, ON: OISE Press. 
Omoto, A. M. (Ed.). (2005). Processes of community change and social action. Mahwah, NJ: Erlbaum.

Prentice, M. (2007). Social justice through service learning: Community colleges at ground zero. Equity \& Excellence in Education, 40, 266-273.

Scott, S. M., \& Chovanec, D. M. (1994). Critical philosophy-in-action: Power and praxis. Canadian Journal for the Study of Adult Education, 8(1), 31-40.

Taylor, L. (1998). Citizenship, participation, and democracy: Changing dynamics in Chile and Argentina. New York: St. Martin's Press.

Tupper, J. (2007). From care-less to care-full: Education for citizenship in schools and beyond. Alberta Journal of Educational Research, 53(3), pp. 259-272.

Veugelers, W. (2007). Creating critical democratic citizenship education: Empowering humanity and democracy in Dutch education, Compare, 37(1), 103-111.

Wang, Y., \& Jackson, G. (2005). Forms and dimensions of civic engagement. Michigan Journal of Community Service Learning, 11(2), 39-48.

Westheimer, J., \& Kahne, J. (2004). Educating the "good" citizen: Political choices and pedagogical goals. Political Science and Politics, 37(2), 241-247. 